\title{
ИСКУССТВОВЕДЕНИЕ
}

\section{ХУДОЖЕСТВЕННАЯ ИНТЕЛЛИГЕНЦИЯ В СОВРЕМЕННОЙ РОССИИ: ПОТЕНЦИАЛ ВЛИЯНИЯ НА ОБЩЕСТВО}

\author{
А. Д. Бородай \\ (Московский гуманитарный университет)
}

\begin{abstract}
Аннотация: В статье рассматривается роль художественной интеллигенции в общественной жизни современной России. Потенциал воздействия деятелей культуры и искусства на социум традиционно был всегда значительным. Автор рассматривает механизмы влияния художественной интеллигенции на общество, показывая традиции и новые тенденции.
\end{abstract}

Ключевые слова: художественная интеллигенция, расслоение, власть, влияние на общество, профессиональная деятельность, творческая молодеж, социальная ответственность.

\section{ARTISTIC INTELLIGENTSIA IN CONTEMPORARY RUSSIA: POTENTIAL IMPACT ON SOCIETY}

\author{
A. D. Boroday \\ (Moscow University for the Humanities)
}

\begin{abstract}
The article deals with the role of artistic intelligentsia in the public life of modern Russia. The capability for influencing society in general has always been significant in people of culture and art. The author takes a detailed look at the mechanisms of such influence, with a special focus on both traditions and new trends.

Keywords: artistic intelligentsia, stratification, power, influence on society, professional activity, creative youth, social responsibility.
\end{abstract}

На общественную жизнь современной России оказывают свое влияние многие факторы. Среди них: государственные институты, политические структуры, общественные организации, средства массовой информации, реклама и связи с общественностью. На протяжении значительного периода нашей истории особое место в этой миссии занимала интеллигенция. Важная роль в социуме принадлежит знаковым персонам. В новейшей истории нашей страны к таким людям можно отнести и недавно ушедших из жизни, и ныне живущих: академика Д. С. Лихачева, писателя А. И. Солженицына, философа А. А. Зиновьева, музыкантов М. Л. Ростроповича и В. А. Гергиева, поэта Е. А. Евтушенко, писателей Д. А. Гранина и В. Г. Распутина, скульптора 3. К. Церетели, художника И. С. Глазунова, ки- 
норежиссера К. Г. Шахназарова, певца И. Д. Кобзона и многих других. Это те люди, мнение которых по различным проблемам жизни всегда было интересно обществу.

В нашей стране действуют более 600 театров, свыше 100 симфонических оркестров, в художественных мастерских творческий процесс ведут 40 тысяч художников, снимаются художественные фильмы, издаются книги. В каждом регионе существуют филармонии, создано множество концертных организаций. Необходимо отметить, что большое количество российских музыкантов и музыкальных коллективов востребовано на мировой сцене. По мнению дирижера Валерия Гергиева, 20\% звучащей в мире классической музыки - российская (Валерий Гергиев ..., 2012: Электр. ресурс). Российские музыканты, артисты балета, вокалисты, кинематографисты, театральные режиссеры и актеры, литераторы, художники в условиях современной мировой конкуренции сохраняют лидерство и достойно представляют российскую культуру в мире.

Влияние художника на социум имеет очень большое значение. Искусство во многом наполняет и определяет духовную жизнь общества, развивает человека, переключает его на другие сферы деятельности. Искусство стимулирует творческое отношение к жизни, к профессиональной деятельности. Хорошая книга, познавательная выставка, музыкальные произведения, интересные спектакли, кинофильмы создают позитивное настроение. Это является важным показателем качества жизни. Творческая элита, в первую очередь, несет ответственность за позитивные тенденции развития страны.

Феномен интеллигенции продолжает привлекать внимание российских исследователей. При Ивановском государственном университете работает Научно-исследовательский институт Интеллигентоведения, издается специализированный журнал «Интеллигенция и мир», проводятся научные конференции в ведущих вузах страны по проблемам интеллигенции. Появились интересные публикации по новому видению места и роли интеллигенции в современном обществе. Проблема интеллигенции и ее роль в обществе привлекает интерес многих ученых. Известный ученый, социолог В. А. Луков в своем исследовании «Миссия интеллигенции в современном российском обществе» отмечает, что часть интеллигенции, прежде всего деятелей искусства, имеют достаточные материальные и финансовые возможности в реализации культурной проповеди (постановка кинофильмов, театральных спектаклей, написание художественных произведений, где есть простор для демонстрации авторских картины мира и понимания жизни (Луков, 2006). Член-корреспондент РАН, известный социолог Ж. Т. Тощенко в статье «Старая» и «новая» интеллигенция: современные реалии» проанализировал принципы статуса «интеллигенции»: 
служение народу, общественно значимые цели, «соль», совесть, честь своего народа, гражданская ответственность перед страной, интернационализм как уважение к другим народам. Профессор Э. Б. Ершова отметила в современной интеллигенции не только ее природные положительные качества (талант, желание дарить свое искусство народу, болеть за справедливость и происходящие несчастья), но и негативные, которые стали вырабатываться у нее с ухудшением системы образования, изменением нравственных ценностей, преобладанием стремления к обогащению и так далее. Об этом она сделала доклад на конференцию в Иваново (Ершова, 2013).

Разница во взглядах на российскую интеллигенцию в целом, и соответственно на художественную, ставит перед учеными многие вопросы. Такие, как например: выполняют ли свою профессиональную миссию российские деятели культуры и искусства? По нашему мнению, не просто выполняют, а делают это очень профессионально. Несмотря на все противоречия в культурной политике советского периода нашей истории, удалось сохранить главное - творческие школы в различных видах искусства (Бородай, 2013). Этим было обеспечено воспроизводство кадров для сферы искусства и культуры. В этот период получила развитие система художественного образования. Ее структура предполагает три уровня профессиональной подготовки. Первый уровень включает в себя детские школы искусств (музыкальные, художественные, хореографические), являющееся необходимой базой и фундаментом будущего профессионального образования. Ко второму уровню относятся училища или колледжи искусств - образовательные учреждения среднего профессионального образования, дающие выпускнику альтернативные возможности, в частности, работать по приобретенной специальности или продолжить обучение в высшем учебном заведении. Третий профессиональный уровень - это высшие учебные заведения искусств, в котором повышается и закрепляется уровень профессиональных умений и навыков, уже полученных на предшествующем уровне образовании.

Как выглядит в целом система высшего художественного образования? Для конкретики следует сразу отметить, что кадры для сферы искусства и культуры в Российской Федерации готовят примерно 100 вузов. В системе Министерства культуры РФ находится 46 творческих вузов. В том числе 11 консерваторий, 8 институтов и академий искусств, 7 театральных вузов, 2 вуза изобразительных искусств, 14 вузов культуры и искусства, 2 вуза кинематографического профиля, 2 хореографических вуза. Около 20 вузов подчиняются Министерству образования и науки РФ. Еще 6 вузов подчиняются региональным министерствам культуры (Белгород, Волгоград, Тамбов, Чебоксары, Якутск). В системе Российской академии художеств работает 2 вуза художественного профиля: Москов- 
ский государственный академический художественный институт им. В.И.Сурикова и Санкт-Петербургский государственный академический институт живописи, скульптуры и архитектуры им. И. Е. Репина. Отдельная группа вузов искусства и культуры, их более 20-ти, принадлежит к негосударственному сектору высшего образования.

Как трудно сегодня выпускнику творческого вуза найти работу? Какие мнения об этом можно услышать сегодня? Вот одно из них. В интервью газете «Караван» в ноябре 2012 г. народный артист РФ Владимир Винокур говорил: «Я не скучаю по тоталитарному прошлому, но ностальгия по советским временам во мне живет.... Мы были защищены государством. Сегодня культура стала бизнесом. В этом я убедился, когда хотел помочь начинающей артистке оперного театра Марии Новиковой и не смог при всех своих званиях и регалиях. Эта девушка феноменальных вокальных данных так и не смогла пробиться на сцену, хотя были и клипы, и показы, и участие в “новой волне”. Сегодня она поет с итальянским певцом. Думаю, что мир еще о ней узнает» (Владимир Винокур ..., 2012: Электр. ресурс).

Есть еще один немаловажный аспект, который приводит к разочарованиям после окончания творческих вузов. Это уровень заработной платы. По сравнению с оплатой труда менеджеров различных компаний, специалистов в области туризма, рекламы, связей с общественностью он существенно ниже. По этим проблемам автору статьи удалось побеседовать с деканом факультета искусств Санкт-Петербургского гуманитарного университета профсоюзов, народным артистом России, профессором Романом Борисовичем Громадским. Этот известный актер и талантливый педагог влюблен в своих студентов, каждого после окончания учебы индивидуально трудоустраивает в театры северной столицы. При этом мэтр в разговоре сетовал на трудности, отсутствия вакансий, незначительную начальную ставку начинающего актера. В беседе им было высказано мнение, что часть зачисленных студентов не выдерживают учебного ритма и «сходят с дистанции», не дотянув даже до «экватора» периода обучения. Он рассказал, что в его практике был случай, когда одну достаточно способную выпускницу не удалось трудоустроить в театр после окончания вуза. Она самостоятельно нашла работу менеджера в туристическом агентстве и успешно справлялась со своими обязанностями. Спустя некоторое время педагогу удалось договориться с руководителем одного из театров о ее трудоустройстве. Однако эта выпускница отказалась переходить в театр на зарплату 10 тысяч рублей, потому что за свою работу в сфере туризма она получала в три раза больше.

Высказывается мнение, что традиционная для России роль интеллигенции в жизни общества в современных условиях изменилась. Она стала менее заметной. В чем причина? Почему в XIX и XX веках интеллигенция 
выполняла свою социальную миссию, а в XXI веке перестает ее выполнять? В России традиционно волю народа, его чаяния выражала интеллигенция. В XIX веке основная часть населения была неграмотной. В обществе было значительное расслоение по социальному признаку. Интеллигенция считала себя ответственной за преобразования в обществе, улучшение жизни народных массам. В советский период истории социальная роль интеллигенции сохранялась в силу традиций, но не только. Идеология предполагала воспитательную роль интеллигенции в обществе, особенно художественной. Для эффективного управления и контроля за этой миссией были созданы творческие союзы, работала жесткая цензура за содержанием художественных произведений. Даже музыка подвергалась цензуре. Известно, что газета «Правда» в январе 1936 г. опубликовала редакционную статью «Сумбур вместо музыки» по поводу оперы Д. Д. Шостаковича «Леди Макбет Мценского уезда». В статье отмечалось, что «слушателя с первой же минуты ошарашивает в опере нарочито нестройный, сумбурный поток звуков. Обрывки мелодии, зачатки музыкальной фразы тонут, вырываются, снова исчезают в грохоте, скрежете и визге. Следить за этой «музыкой» трудно, запомнить ее невозможно» (Сумбур вместо музыки, 1936). Вот такую роль музыкального критика выполняла главная партийная газета. Публикация с критической тональностью относительно музыкальных произведений была не единственной.

Каков механизм влияния художественной интеллигенции на общество в современных условиях? Есть, по нашему мнению, два основных вида воздействия. Первый - через художественное произведение, в котором поднимаются важные социальные проблемы современного общества. Второе - выражение точки зрения мастеров культуры и искусства через средства массовой информации по актуальным, животрепещущим проблемам жизни страны и народа. «Властители дум» во многом перестали быть таковыми, потому что перестала быть таковой «самая читающая страна в мире». Интерес к книге значительно снизился. Причины здесь разные. Выросло другое поколение, которое упустили в этом смысле в процессе воспитания как элемента образования в школе. Появились альтернативы книге. Прежде всего, Интернет. Сам по себе он очень важный источник информации и коммуникации. В московском метро, например, вместо чтения книг молодые люди с наушниками слушают музыку. В этом нет ничего плохого, но это занятие для ленивых людей. Здесь не надо думать, напрягаться. На молодежном сленге это звучит так: «не надо париться».

Но есть и другая сторона этого процесса. Литература, которая сегодня издается, в значительной степени принадлежит к виду развлекательного чтива. Написать серьезную книгу, по мнению самих писателей, в наше время сложно. В декабре 2012 г. Союз писателей Москвы проводил твор- 
ческую конференцию «Москва литературная: двадцать лет спустя». Писатели столицы планировали обсудить «самые острые вопросы писательского дела в России». Накануне конференции секретарь Союза Евгений Сидоров дал интервью корреспонденту газеты «Московский комсомолец». Писателю был задан вопрос: «Евгений Юрьевич, как вы оцениваете литературный процесс сегодня?» В ответ было сказано: «Особого оптимизма нет. Есть литература, но нет литературного процесса. Как нет смысла у нашего государства, так нет в писательском деле общей реки, потока». Журналист уточнил: «А что касается смысла государства?» Секретарь Союза продолжил: «Ну а вы знаете, что такое Россия, куда она идет? Но что будет завтра - никто не знает... И отсюда жуткое недоверие друг к другу и к власти; причем, как говорил один американский философ, недоверие - это колоссальный налог на экономическую деятельность. Нет «завтра», - не может существовать. скажем

Второй вид воздействия перестал быть интересным средствам массовой информации. Телевидение, например, в значительной степени перестало выражать общественные интересы. Признавая этот факт, власть создает общественное телевидение. Что нам предлагают телевизионные программы на ведущих каналах? Жизнь звезд шоу-бизнеса через «замочную скважину». Для чего? Это развлекает, привлекает к экранам обывателей. Телевизионным каналам необходимо собрать у экрана как можно больше зрителей. От этого зависит рейтинг канала, обьем и стоимость секунды эфирного времени рекламной информации. В современных условиях ведется ожесточенная борьба за рейтинг, т. е. за деньги рекламодателя. В чем здесь интерес артистов? Они стараются, чтобы зрители о них не забывали и помнили каждый день. Здесь также ведется борьба за деньги зрителей, которые должны прийти в зрительные залы, купив в кассах билеты. Так формируется интерес не искусству, а к артисту, неприглядные стороны жизни которого придали гласности. По большому счету, общественных интересов в этом нет. Чаще всего актеры, писатели, художники, кинематографисты выражают свою благодарность в процессе их награждения государственными наградами. В этой ситуации проблемы страны и общества затрагивать не принято.

Власть заискивает перед художественной интеллигенций. Как бы просит поддержки и примера этой поддержки для широких масс. Больше чем кого-либо награждают государственными наградами и почетными званиями деятелей культуры и искусства. Если, в свое время А.И.Солженицын отказался от государственной награды, потому что он не мог оценить положительно усилия государства по «сбережению народа», организации справедливого общества, то ни один представитель художественной интеллигенции этого не сделал. Особенно активно ходатайствуют о награж- 
дении звезд шоу-бизнеса. Для них награда - это промоушен, реклама.

В списке государственных наград Российской федерации установлено 59 почетных званий по различным отраслям деятельности. Для сферы культуры и искусства предусмотрены: «Народный артист Российской Федерации», «Народный художник Российской Федерации», «Народный архитектор Российской Федерации», «Заслуженный артист Российской Федерации», «Заслуженный деятель искусств Российской Федерации», «Заслуженный художник Российской Федерации», «Заслуженный работник культуры Российской Федерации». Деятели культуры и искусства награждаются орденами и медалями, им присуждаются государственные премии.

В сфере искусства из почетных наград самым престижным является звание «Народный артист Российской Федерации». Первым обладателями звания «Народный артист Республики» стали Ф. И. Шаляпин (1918 г.), М. Н. Ермолова (1920 г.), Л. В.Собинов (1923 г.), В. Э. Мейерхольд (1923 г.) и другие. В 1936 г. было учреждено звание «Народный артист СССР». В этом же году 13 человек были удостоены этого высокого звания. В этой группе были К. С. Станиславский. В. И. Немирович-Данченко, В. И. Качалов, А. В. Нежданова, Б. В. Щукин, А. А. Васадзе и другие. В 1930-е и 1940-е годы требования к соискателям звания «Народный артист СССР» были очень высокими. Достаточно сказать, что величайший композитор Сергей Прокофьев не был удостоен этого звания. В более поздний период не получили его и любимые народом артисты Андрей Миронов, Сергей Филиппов, Леонид Быков, Леонид Куравлев. За 55 лет в период с 1936 по 1991 гг. звание «Народный артист СССР» в нашей стране получили 1007 человек. Самым молодым обладателем этого звания была певица Куляш Бейсеитова (1936 г.). Ей было 24 года. Муслим Магомаев стал народным артистом СССР в 31 год. Народными артистами Российской Федерации за последние два десятилетия с 1992 по 2013 годы (на 08.04.13 г.) стали 1312 деятелей искусства.

О чем говорят эти цифры? В стране с населением в 280 млн чел. в год примерно 18 человек становились народными артистами. Если прежний подход использовался бы в наше время, то количество таких званий было бы не более десяти в год. За 22 года новейшей истории ежегодно это высокое звание уже присваивалось примерно 60-ти деятелям искусства. Таким образом в 6 раз увеличилась скорость присуждения звания «Народный артист РФ». Слово «народный» ведет свое начало с лат. popularis, т. е. популярный, известный в народе. Это буквальный смысловой перевод. В нашем случае стать «народным» - значит получить высшее признание в обществе. За последние 20 лет значительно расширена география награждаемых. Например, в списке «народных» - актриса драматического театра Комсомольска-на-Амуре, актер Камчатского областного театра 
драмы и комедии, артист Сахалинского международного театрального центра имени А. П. Чехова. В предыдущей период нашей истории в этих труппах в лучшем случае, было не более двух-трех заслуженных артистов. Ежегодно звания «Народный артист Российской Федерации» получают представители национальных искусств из Татарстана, Башкортостана, Тувы, Мордовии, Марий Эл, Коми, Дагестана, Чечни и других территорий. Для федеративного государства это очень важно. В списках деятелей искусства, которым присвоено звание «народный», есть рок-музыканты (Андрей Макаревич, Александр Градский), барды (Александр Розенбаум, Олег Митяев), представители шоу-бизнеса (Олег Газманов, Николай Расторгуев). В будущем жизнь подтвердит или опровергнет обоснованность решения о присвоении им звания «народный артист».

В современных условиях сохраняются и традиционные взгляды в позициях художественной интеллигенции по вопросам жизни общества.Их, правда, не много и звучат они не так громко. По мнению рок-музыканта Андрея Макаревича, власть не хочет думать о том, как помирить расколовшееся на две части население страны. Власть вполне устраивает ситуация, когда народ раскалывается. И те, кто поддерживают - те народ, а те, кто не поддерживают - враги. Макаревич выступил с открытым обращением к президенту России Владимиру Путину на страницах газеты «Московский комсомолец», в котором рассказал о масштабах бедствия с «распилом» бюджета. «Откаты», по словам певца, съедают до двух третей всех поступлений в госказну. Дав ряд гастролей в городах России, Макаревич, потрясенный размахом коррупции, не смог закрыть глаза на проблему. «Вам, конечно, хорошо знакомо слово “откат”. Еще 5-6 лет назад средний откат по стране составлял 30\%. Сегодня это 70\%. Мне достоверно известен случай, когда откат составил 95\%. Об этом сегодня знает вся страна. Знает и молчит», - написал он (Открытое письмо ..., 2012: Электр. ресурс). Через несколько Андрей Макаревич сделал новое обращение к Президенту через ту же газету - теперь по поводу запрещения усыновления американцами сирот из России. Он писал: «Своим постановлением дума практически лишает этих детей права на жизнь. Детские жизни недопустимая разменная карта в политических играх» (Андрей Макаревич перестал ..., 2012: Электр. ресурс).

Руководитель рок-группы ДДТ Юрий Шевчук на концерте 7 марта 2010 г. в спорткомплексе «Олимпийский» в Москве неожиданно для всех остановил свое выступление и обратился к зрителям. Он говорил: «Сейчас у нас в стране система выстроила жестокую, жесткую, бесчеловечную власть. Народ мучается не только в тюрьмах и лагерях, но и в детских домах, больницах... По-моему, власть должна быть прежде всего человеческой, гуманной, доброй по отношению к своим гражданам; тогда и 
народ подобреет. И когда в сердце любовь, тогда все живо. В политике мало любви... Я болен этой болезнью российской интеллигенции конца XIX века - начала XX-го: просвещение сейчас крайне необходимо. Очень много просто невежественных людей» (Рок-звезда Юрий Шевчук ..., 2010: Электр. ресурс).

Однако, такие публичные высказывания, пожалуй, исключение. Многие известные руководители творческих организаций чаще обращаются к власти за помощью. Например, очень трудное материальное положение существует в театрах. У председателя Союза театральных деятелей нет альтернативы обращению за помощью к президенту. Потому что тысячи актеров по всей России страдают от мизерной зарплаты, отсутствия денег на новые постановки. Эта помощь оказывается. Народный артист, председатель СТД РФ Александр Калягин публично благодарит власть в лице В.В.Путина за поддержку и помощь. Здесь другого сценария быть не может, потому что трудно представить, что актер бросит служение театру и пойдет искать другую работу. Иного деятели искусства, как правило, делать ничего не могут. В этом их зависимость от власти и общества.

Новым явлением в политической жизни России в конце 2011 г. стали массовые протестные выступления. Протестное движение - это новая форма влияния части новой интеллигенции на общество. Повод для протестного движения - это политические и социально-экономические проблемы развития страны. Как показывает анализ высказываний их участников - это зависимость судебной системы от политической власти. Кадровая политика, которая допускает на ключевую роль в управлении армией министра обороны человека, который ни по моральным и по профессиональным критериям никак не мог занимать эту должность. Социально-экономическое и финансовое расслоение в обществе. Коррупция и неадекватные меры по ее искоренению. Сращивание власти и православной церкви вопреки положению Конституции. Примером этого является судебное решение, когда за хулиганство панк группа Pussy Riot в Храме Христа Спасителя и за гибель двух человек, сбитых автомобилем по вине пьяного иеромонаха суд назначает одинаковую меру ответственности - три года лишения свободы. Масштаб протестного движения можно измерять количеством сторонников А. Навального на выборах мэра Москвы (27\%) в 2013 г. В различных источниках приводят цифру от 10 до 15\%. Другой показатель - это число участников на Болотной и проспекте Сахарова. Однако в конце 2011 г. детонатором массового социального протеста явилась, по мнению его участников, подтасовка результатов выборов в Государственную Думу. В результате этого партия «Единая Россия» сохранила большинство в Думе. В Москве, например, по рассказам представителей, участковых комиссий главы управ переписывали протоколы, до- 
бавляя проценты до установленных показателей. Количество участников митинга «За честные выборы», который проходил на проспекте Сахарова 24 декабря 2012 года, по подсчетам специалиста по геодезии Н. Помещенко составило 56 тысяч человек (Тюменцева, 2011: Электр. ресурс).

Впервые понятие «креативная экономика» появилось в журнале Business Week в августе 2000 г. В этот же год увидела свет книга американского экономиста Ричарда Флориды «Креативный класс: люди, которые меняют будущее». В дальнейшем она была переведена на русский язык и издана в России (Флорида, 2007). Это специальный сектор экономики, основанный на интеллектуальной, творческой деятельности. В ее основе лежат творческие технологии с применением проектного мышления, креативное моделирование, практическая направленность получения оригинального продукта. На конференция ООН по торговле и развитию 31 марта 2011 г. в штаб-квартире в Нью-Йорке был представлен доклад «Креативная экономика - отчет за 2010 г.». В докладе говорилось, что креативная индустрия - один из источников динамичного экономического развития в современных условиях. Это примета информационного общества. Приводились данные, что в период с 2002 по 2008 гг. объем экспорта товаров креативной индустрии увеличились в два раза, составив 600 млрд. долл. В это время объем мировой торговли снизился на $12 \%$, однако экспорт продукции креативной индустрии сохранил тенденцию динамичного роста и составил 14\%. Мировым лидером в креативной экономике признана Великобритания. В этой стране разработана правовая база, стратегические и политические документы развития национальной экономики через экономическое, культурное и социальное взаимодействие. Координирует эту работу Министерство по культуре, информации и спорту Великобритании. В сектор креативной экономики включены реклама, архитектура, прикладное художественное творчество, кинематограф, дизайн, моделирование одежды, музыка, исполнительские искусства, пресса, радио, телевидение, цифровые и мультимедийные технологии, интерактивные игры, программное обеспечение. Справедливости ради необходимо отметить, что еще В 1947 г. была опубликована книга «Диалектика Просвещения», где в главе «Культурная индустрия: Просвещение как обман масс» социологи Теодор Адорно и Макс Хоркхаймер ввели понятие «культурная индустрия». Они резко критиковали процесс массовизации культурной продукции и услуг в послевоенной Америке и Европе. Именно это понятие в дальнейшем трансформировалось в «творческие индустрии», затем и в «креативные индустрии» с «креативным классом».

Иной подход к понятию термина «креативный класс» в 2008 г. предложил президент Фонда эффективной политики Глеб Павловский. По итогам исследования восприятия политики и власти он разделил услов- 
но российское общество на «три кластера». Первый из них составляет большинство, лояльно относящееся к власти. Политизированное меньшинство представляет из себя вторую группу (кластер), находящееся в оппозиции к власти. Третью группу он назвал «креативным классом». По мнению эксперта, это большая группа, составляющая до 20\% населения. Это представители среднего класса, которые вовлечены в новую систему экономических отношении, в частный бизнес. Такие люди формируют стиль жизни, моду на новые общественные запросы. В эту группу, по мнению Г. Павловского входят журналисты, рекламисты, пиарщики, технологи, пользователи Интернета. По сути, здесь есть совпадение с классическим пониманием креативного класса как профессиональной группы. Однако в основу критериев отбора в Фонде эффективной политики были положены не профессиональные, а политические предпочтения. Креативный класс рассматривался, прежде всего, как коммуникативно активная часть общества. В этом его принципиальное отличие. Эффективная коммуникация в сетях стала важнейшим компонентом «креативного класса», главным способом публичного проявления позиций его представителей (см.: Билевская, 2008: Электр. ресурс).

Свои характеристики «креативному классу» в России дал В. В. Путин в своем обращении к Федеральному Собранию 12 декабря 2012 года: «Отдельно хочу сказать о социальной сфере. За специалистами, работающими здесь, закрепилось казённое определение “бюджетники”. Это, однако, те люди, которые имеют высокое образование, квалификацию; по содержанию своего труда, по культурным потребностям, по социальной активности они часть так называемого креативного класса. Креативный класс, а если использовать традиционное слово, интеллигенция - это прежде всего врачи, учителя, преподаватели вузов, работники науки, культуры, и такие люди работают в каждом регионе, в каждом посёлке, в каждом городе. В то же время по уровню доходов они пока не дотягивают до среднего класса, вынуждены отказывать себе и в нормальном отдыхе, и в жизненном комфорте, и в профессиональном развитии, искать постоянно дополнительные заработки» (Послание Президента ... , 2012: Электр. ресурс). Однако к «креативному классу», который участвовал в протестном движении, В. В. Путин отнесся критически. Более того, на встрече с писателями в ноябре 2013 г. В. В. Путин отметил, что проблемы образования являются результатом проникновения в Министерство образования и науки РФ представителей «креативного класса». «По поводу всех несуразностей, излишних сложностей, непонятных часто никому, - это результат того, что представители так называемого креативного класса пробрались в Министерство образования и там все это рисуют. Это результат их работы» Президент добавил, что всем хочется, чтобы везде были предста- 
вители «креативного класса», что они, как правило, люди с творческим началом и делают много хорошего, «но иногда перебарщивают».

Таким образом, творческий и социальный потенциал художественной интеллигенции влияния на общество сохранился, по законам сохранения энергии. Однако новые реалии жизни повлияли на его концентрированное воздействие. В каких новых обстоятельствах живет современная художественная интеллигенция? С профессиональной точки зрения для деятелей культуры и искусства открылись новые возможности мировой сцены. Многие великие музыканты из России приглашаются в разные страны руководить симфоническими оркестрами, организуются их гастрольные туры, часть из них уезжает на работу в другие страны, в том числе целыми камерными театрами. В России руководителям творческих коллективов платят, зачастую, зарплату несоизмеримую со ставками актеров или музыкантов. Это принцип используется повсеместно: в вузах, в школах, в театрах и т. д. С этого начинается расслоение в обществе по социально-экономическому признаку. Поэтому руководитель стимулируется поддержать внутреннюю политику власти. В его экономические интересы не входит конфликт с властью. Сегодня ставится новая, но достаточно традиционная для художественной интеллигенции задача: влиять на нравственное состояние общества. Безусловно влиять через художественные произведения, социальную активность в этом направлении.

Попытаемся сформулировать творческий и социальный потенциал современной художественной интеллигенции. Это может быть влияние на целый комплекс проблем современного общества. На власть с помощью профессионального авторитета в решении важнейших вопросов культурной политики в современных условиях. Определение вектора развития страны. На общество с целью утверждения культурных стандартов социума, обогащения духовной жизни. На профессиональную среду для утверждения стандартов творчества и уровня мастерства в разных видах искусства. На систему художественного воспитания и образования в стране, участие в подготовке кадров для искусства. На развитие гражданского общества через участие в работе творческих союзов и организаций, других общественных структур. На имидж страны и престиж российского искусства в мировом общественном мнении (Бородай, 2012).

Каковыми могут быть механизмы влияния? На наш взгляд, они могли бы представлять целый комплекс мероприятий. Во-первых, политическая инициатива по совершенствованию (изменению) законодательства с целью создания наиболее эффективных условий для развития страны. В качестве примера можно привести обращение с открытым письмом к президенту творческой элиты по поводу проекта Закона об образовании, который в представленной редакции Министерства образования и нау- 
ки РФ мог упразднить начальное художественное образование в стране. Во-вторых, превращение творческих союзов и организаций в реальные институты гражданского общества по реагированию на актуальные проблемы жизни страны. Ведущая роль в них должна принадлежать творческой элите. В-третьих, делегирование видных деятелей искусства в представительные органы власти и социальные институты на федеральном и региональном уровнях. Профессиональное участие в специализированных комитетах и комиссиях Государственной Думы РФ, Общественной палаты РФ, при Президенте РФ. В-четвертых, выступления творческой интеллигенции в средствах массовой информации по актуальным проблемам жизни страны. Важно формировать культуру реагирования на публикации и выступления. Она за последний период утеряна. В-пятых, проведение социальных акций и программ таких, как волонтерское движение «Подарим жизнь», которое возглавляет актриса театра «Современник» Чулпан Хаматова. Другой пример - участие в программе первого канала телевидения «Жди меня» с участием актеров Марии Шукшиной и Михаила Ефремова.

Важнейшим механизмом влияния художественной интеллигенции является творческая деятельность, чтобы дарить людям свое искусство. От этого зависит атмосфера духовной жизни нашего общества и все мировой цивилизации. В основе высокого искусства и мастерства лежит огромный труд. По-другому высокого искусства достичь невозможно. На примере жизни этих людей необходимо с помощью средств массовой информации, прежде всего, телевидения формировать у гражданина России, молодого поколения творческий стиль жизни.

\section{СПИСОК ЛИТЕРАТУРЫ}

Андрей Макаревич перестал называть Путина «уважаемым». Известный музыкант написал еще одно Открытое письмо президенту России (2012) [Электронный ресурс] // Московский комсомолец. 23 декабря. URL: http://www.mk.ru/politics/article/2012/12/23/791083-andrey-makarevichperestal-nazyivat-putina-quotuvazhaemyimquot.html (дата обращения: 12.01.2015).

Билевская, Е. (2008) Свободный мир Глеба Павловского [Электронный ресурс] // Независимая газета. 5 октября. URL: http://www.ng.ru/ politics/2008-10-05/100_pavlovsky.html (дата обращения: 12.01.2015).

Бородай, А. Д. (2012) Культурная элита России: опыт идентификации // Вестник Казанского государственного университета культуры и искусств. № 3. Ч. 1. С. 30-36.

Бородай,А.Д.(2013) Художественное образование в современной России: опыт структурного анализа // Знание. Понимание. Умение. № 2. С. 24-29. 
Валерий Гергиев: «Как мы лечим культурную нищету?» (2012) [Электронный ресурс] // Аргументы и факты. № 51. URL: http://www.aif.ru/ culture/39010 (дата обращения: 12.12.2014).

Владимир Винокур: случайности не случайны (2012) [Электронный ресурс] // Караван (газета). 14 апреля. URL: http://www.caravan.kz/ article/43716 (дата обращения: 12.01.2015).

Ершова, Э. Б. (2013) Приспособленчество интеллигенции к власти: жизненная необходимость или осознанная необходимость? (К постановке вопроса) // Интеллигенция современного мира в ее многообразии. Материалы XXIV Международной научно-теоретической конференции. Иваново. 26-28 сентября 2013 г. Иваново : Изд-во ИвГУ. С. 22-24.

Луков, Вал. А. (2006) Миссия интеллигенции в современном российском обществе // Гуманитарное знание :тенденции развития в XXI веке : В честь 70-летия Игоря Михайловича Ильинского / под общ. ред. Вал.А.Лукова. М. : Изд-во Нац. ин-та бизнеса. 680 с. С. 37-47.

Открытое письмо Андрея Макаревича Путину. Потрясенный рокмузыкант обратился к Президенту (2012) [Электронный ресурс] // Московский комсомолец. 6 августа. URL: http://www.mk.ru/politics/ article/2012/08/06/733856-otkryitoe-pismo-makarevicha-putinu.html (дата обращения: 12.01.2015).

Послание Президента Федеральному Собранию (2012) [Электронный ресурс] // Президент России. 12 декабря. URL: http://www.kremlin.ru/ news/17118 (дата обращения: 12.01.2015).

Рок-звезда Юрий Шевчук вместо дежурной речи толкнул слово против Кремля России (2010) [Электронный ресурс] // Радио Аззатык. 10 марта. URL: http://rus.azattyq.org/content/yuryi_shevchuk_russian_rock_musician_ against_power/1979513.html(дата обращения: 12.01.2015).

Сумбур вместо музыки (1936) // Правда (газета). 28 января.

Тощенко, Ж. Т. (2012) «Старая» и «новая» интеллигенция: современные реалии // «Новая « и «старая» интеллигенция: общее и особенное / под общ. ред. Ж. Т. Тощенко. М. : РГГУ. С. 16-26.

Тюменцева, О. (2011) Инженер-геодезист на митинге в Москве насчитал 56 тысяч человек [Электронный ресурс] // Великая эпоха. 24 декабря. URL: http://www.epochtimes.ru/content/view/56351/3/ (дата обращения: 12.01.2015).

Флорида, Р. (2007) Креативный класс: люди, которые меняют будущее / пер. с англ. М. : Издательский дом «Классика-XXI». 355 с. 
Бородай Александр Дмитриевич - доктор исторических наук, профессор, заслуженный работник культуры РФ, декан факультета рекламы Московского гуманитарного университета. Адрес: 111395, Россия, г. Москва, ул. Юности, д. 5, корп. 3. Тел.: +7 (499) 374-54-51. Эл. адрес: ad.bor@ mail.ru

Borodai Alexander Dmitrievich, Doctor of Science (history), professor, the dean of the Advertising Department, professor of the Advertising Theory and Mass Communications Department, Moscow University for the Humanities, Honored Cultural Worker of the Russian Federation. Postal address: 5 Yunosti St., B. 3, of. 516, Moscow, Russian Federation, 111395. Tel.: +7 (499) 374-54-51. E-mail: ad.bor@mail.ru 